\title{
The Psychological Constraints of Using Japanese Among Indonesian Students
}

\author{
Suyanti Natalia \\ Faculty of Cultural Sciences, Hasanuddin University, Makassar, Indonesia \\ Muhammad Darwis \\ Faculty of Cultural Sciences, Hasanuddin University, Makassar, Indonesia \\ Kaharuddin \\ Faculty of Cultural Sciences, Hasanuddin University, Makassar, Indonesia \\ Asriani Abbas \\ Faculty of Cultural Sciences, Hasanuddin University, Makassar, Indonesia
}

\begin{abstract}
This study discusses the psychological constraints for Indonesian students in using Japanese as one of the student learning processes in order to improve speaking skills. The main obstacle for students is the sentence structure which differs between the mother tongue and the target language. The difference between the Japanese sentence structure and the Indonesian sentence structure can be seen in the learners' speech. The discussion in this study presents the influence of the interference structure of the Indonesian language on Japanese speech. Mother tongue interference then becomes a psychological constraint in the use of Japanese among Indonesian students. Research data were obtained through interviews with elicitation. The results of this study indicate that a number of syntactic elements that affect Japanese speech are found in the fields of phrases, clauses and sentences. This is mostly influenced by structural elements in the different syntaxes of Indonesian and Japanese languages, which actually have different cultural aspects. From this, it is evident that foreign language learners, especially Indonesians, have psychological barriers in speaking Japanese because the language is influenced by linguistic environmental factors related to the way Japanese people express things through their language.
\end{abstract}

Index Terms—sociolinguistics, psychological constraints, interference, syntax, Japanese

\section{INTRODUCTION}

Japanese speaking skills are one of the language learning outcome products that are very important for Japanese language learners (Wuisang, 2019). Mastery of speaking skills is very important in foreign language learning as a result of the learning process related to one aspect of the four basic language skills (Vavilova, et al., 2015). Speaking skills, for example, are recognized as communicative events that occur interactively, socially, and contextually (Paola Cabrera-Solano, 2020).

Speaking is the most effective means of communicating and is a person's activity to convey ideas, feelings, thoughts, and so on (Junaidi, et al., 2020). Furthermore, with language, speakers and speech recipients can exchange information, negotiate, and manage friendships (Kafryawan, et al., 2018). In this context, foreign language learning cannot be separated from learning the four basic language skills, namely, speaking, listening, reading, and writing (Rahman, et al., 2019). Of the four language skills, it is considered that listening and reading are inputs in the language learning process and speaking and writing are the output processes of the other two language skills, listening and writing (Shin \& Jung, 2021). The focus of this research is to reveal the psychological barriers to speaking Japanese when learning the Japanese language. Language learning is acquiring the ability to speak and communicate (Krashen, 1989; Weda, et al., 2021). The process of learning to speak requires teachers to provide innovative teaching so that the learning outcomes in terms of speaking skills are achieved through a good process. Students are considered capable of conveying the contents of a conversation to their interlocutor in a foreign language when several good elements such as accent, pronunciation and fluency in using the foreign language being studied, so that the interlocutor is able to understand or be able to understand the contents of the speaker's message.

In the process of learning a foreign language, there is a transition of elements of a language. This phenomenon can lead to language transfer or to borrowed language elements which appear when speaking the foreign language they are learning due to the influence of bilingualism or mastery between languages (Galkina \& Radyuk, 2019). This study discusses the psychological barriers of foreign speakers of Japanese. This is in the realm of sociolinguistics because it is related to the emergence of interference from elements in the field of Indonesian syntax in students' Japanese speech. Interference is a form of deviation from the language rules of the language used (Rahmayana, et al., 2018). It is the 
interference experienced by students in learning Japanese that is the topic of this research study.

Bilinguals face various factors that affect their language processes (Dixon, 2020; Donnelly, et al., 2019). Bilingualism is the status of an individual who is associated with two languages and someone is associated with bilingualism if they are in a group that uses two different languages (Sarfraz, et al., 2016; Miranda, 2012; Sarif and Suganda, 2020). Discussions regarding other areas of speaking skills, for example in the field of psycholinguistics, have also discussed learners' speaking skills as being influenced by different learning conditions and the effects of the four language skills influencing each other (Khresheh, 2020; Purba, 2018; Krashen, 1989). It is widely accepted that language learning is acquiring the ability to be able to speak and communicate in a given language. The foreign language skills of the learners are demonstrated by their ability to speak and how they are able to employ the speaking skills they have acquired as a means of communication in the foreign language they master (Aziz, et al., 2019; Junaidi, et al (2020). Speaking as one of the basic language skills becomes an object of discussion in this study. The learner's speech becomes data that can be collected through interviews in order to be discussed and analysed. Speech as the data collected is speech which is interfered with in terms of syntax by the Indonesian language when the respondent speaks Japanese. According to Weinreich (2010), interference occurs because of changes in the language system related to the contact of the language being used with elements of another language spoken by bilinguals. Interference can be one of the reasons for the use of elements from another language in the speaker's language during a language contact event (Darwis \& Kamsinah, 2019). Interference affects two or more languages that a person learns and then uses in communication; there are cases of two languages that have similar grammatical structures, it is also found that even in this case interference can affect the language being studied (Sugianto \& Kamarudin, 2021). The interference that occurs can result in a negative transfer if there is no similarity between the two languages, i.e. the source language and the target language (Iman, 2020). Language contact and specific cases of such as interference are subjects of interest to be discussed in this study, especially the interference that occurs in both languages, as Indonesian and Japanese have many differences in linguistic terms.

Some characteristics of the Japanese language, such as the phoneme sounds $r$ and 1 , are sounds that are erased because they sound faint or sounds that are pronounced weakly, while in Indonesian they can be pronounced clearly. In terms of morphology, conjugated forms do not exist in Indonesian at the level of verbs and adjectives. At the syntax level, Japanese phrases, clauses, and sentence structures are different from the Indonesian syntax (Tjandra, 2013; 2015). Therefore, students who are studying Japanese in the Japanese Language Studies program at the Nasional University often encounter the interference of these various elements in their speech.

\section{AIMS OF STUDY}

This study aims to: 1) describe the types of interference that occur in students' speech when communicating in Japanese that are caused by Psychological Constraints; and 2) seek alternative solutions to improve students' ability to speak Japanese.

\section{LITERATURE REVIEW}

Sociolinguistics is a field of study that looks at the relationship between language and the context used in that language. The linkage is that the use of language is closely related to social functions (Holmes, 2013). Sociolinguistics is also about the way people use language in different social conditions, as well as the social relations in a community, and how people convey and construct aspects related to social identity through their language.

Wardaugh (2006) states that sociolinguistics is concerned with investigating the relationship between language and society with the aim of improving the understanding of the structure of language and how language functions in communication; similarly, the goal of studying the sociology of a language is an attempt to explore how social structures can be better understood through an understanding of language. There are two terms with respect to the above, namely: 1) Sociolinguistics, also called micro-sociolinguistics and 2) Sociology of language, also called macrosociolinguistics.

According to Thomason (2001), language changes occur as a result of language contact (Perta, 2020). These language changes that occur due to language contact result in a variety of different features in the structure of language interference, all of which include linguistic structures such as phonology, lexical and grammatical structures. This is discussed by Weinreich as a manifestation of linguistic interference that begins with the assumption of the possibility of understanding speech consisting of several elements derived from other languages. This can be thought of or described as an utterance that belongs to the entirety of the language that is conveyed at the time of communication. Meanwhile the elements or utterances that do not belong to the language being used are considered as originating in a process of contact with other languages, namely borrowed and transferred elements. This interference process can be seen as a process of language use that has been deviated due to the influence of other languages. Taking a language element or inserting even the slightest language element from the first language to the second language will cause interference (Novianti \& Dewi, 2008).

Interference can be divided into three main types (Weinreich, 2010), namely 1) phoneme interference; 2) grammatical interference (morpheme and syntax); and 3) lexical interference. The data to be analysed in this study are 
comprised of speech collected from the conversational flow in Japanese that contains examples of interference from the language used by the students in their everyday lives, namely Indonesian. The data were collected based on the type of interference, specifically data where interference appears at the syntactic level in communication. These data came from interviews with students of the Japanese Language Study Program who use the Japanese language. The data were classified based on Weinreich's interference theory as syntactic interference at the level of phrases, clauses, and sentences. The types of language change due to language contact were categorised based on the typology of the influence on the target language structure, namely Japanese, as changes in Japanese language structure belonging to the following types: missing features, additional features, or replaced features.

\section{Methodology}

\section{A. Type of Research}

This research is qualitative research that describes the data based on the environment and its effect on the facts. The basic assumption of this research is that psychological constraints on using Japanese occur among Indonesian Students and are caused by the interference of the syntactic structure of the mother tongue with that of the language being studied, namely Japanese. Thus, learners always feel they are conversing in Japanese but, as a result, their Japanese language development is hampered. This phenomenon is also due to the limited situations in which they can practice Japanese.

\section{B. Population and Sample}

The study population was the students of the Department of Japanese Language, Faculty of Letters, of the Nasional University of Jakarta. The study sample was a purposive sample of 20 people including both male and female respondents (Figure 1).

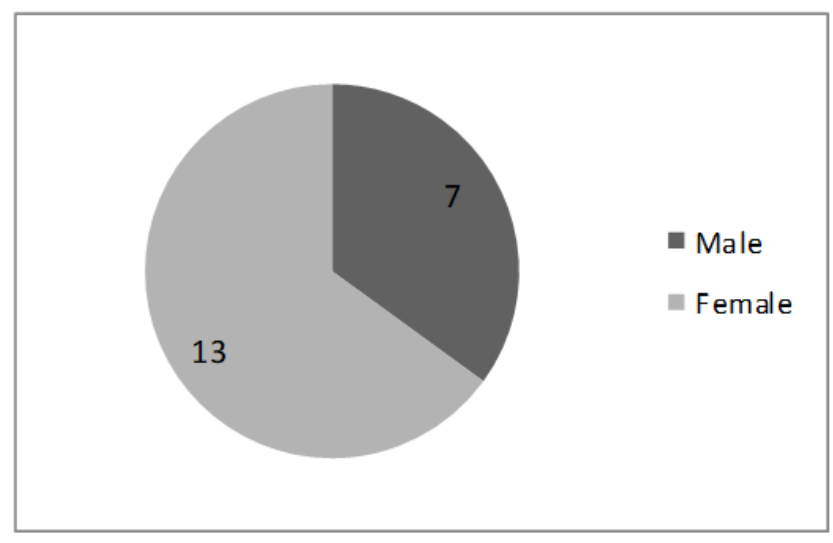

Figure 1. Research Respondents By Sex

Within this sample, the level attained in the basic Japanese language proficiency test varied from Elementary to Advanced (Table 1). The attainment category was based on the results of the test which measured four macro-skills (reading, writing, listening, and speaking).

TABLE 1

STUDENT JAPANESE PROFICIENCY TEST RESULTS

\begin{tabular}{|c|c|c|}
\hline Level & Category & Number of students \\
\hline 5 & Advanced & 3 \\
\hline 4 & Post intermediate & 9 \\
\hline 3 & Intermediate & 0 \\
\hline 2 & Post elementary & 0 \\
\hline 1 & Elementary & \\
\hline
\end{tabular}

\section{Method of Collecting Data}

Data were collected from recordings of students speaking in Japanese to observe and record the emergence of types of interference and their typology. The respondents of this study were students of the Japanese Language Study Program, Faculty of Language and Letters, Nasional University, Jakarta who were studying Japanese in their sixth semester. Japanese speech data was recorded during interview conversations. The data were collected by elicitation so that the conversations developed around a proposed theme, such as conversations about family, daily activities, hobbies and friends, and campus activities.

The stages of data collection were as follows: 1) individual interviews with the choice of theme and the flow of the interview as elicitation; 2) noting the language structures used that had experienced interference; 3) recording the type of influence on the target language structure; 4) classifying the data that had been collected; and 5) analysing the data 
based on this classification.

\section{FINDINGS AND DISCUSSION}

\section{A. Findings}

TABLE 2

SPEECH DATA WiTH MOTHER TONGUE (INDONESIAN) INTERFERENCE

\begin{tabular}{|c|c|c|c|c|}
\hline No & Sentences spoken & Correct Sentences & $\begin{array}{l}\text { Form of syntactic } \\
\text { interference }\end{array}$ & $\begin{array}{l}\text { Influence on the target (Japanese) language } \\
\text { structure }\end{array}$ \\
\hline 1 & $\begin{array}{l}\text { Sorosoro danjikiake o yatte } \\
\text { iru node, sugu ni kazoku o } \\
\text { renraku shimasu }\end{array}$ & $\begin{array}{l}\text { Sorosoro danjikiake o } \\
\text { yaru node, sugu ni } \\
\text { kazoku o renraku } \\
\text { shimasu }\end{array}$ & $\begin{array}{l}\text { going to break the fast } \\
\text { (verbal complement } \\
\text { clause) }\end{array}$ & $\begin{array}{l}\text { Danjikiake o yatte iru replaces danjikiake } \\
\text { o yaru }\end{array}$ \\
\hline 2 & $\begin{array}{l}\text { Boku ni totte wa mendou to } \\
\text { shukudai wa kibishii desu. }\end{array}$ & $\begin{array}{l}\text { Boku ni totte wa mendou } \\
\text { de shukudai wa kibishii } \\
\text { desu. }\end{array}$ & $\begin{array}{l}\text { difficult and strict } \\
\text { (coordinative phrase) }\end{array}$ & $\begin{array}{l}\text { Mendou to kibishii replaces } \\
\text { mendoude kibishii. }\end{array}$ \\
\hline 3 & $\begin{array}{l}\text { Nagai aida matte iru kara, } \\
\text { onaka ga suita ni natta yo. }\end{array}$ & $\begin{array}{l}\text { Nagai aida matte iru } \\
\text { kara, onaka ga suichatta } \\
\text { yo. }\end{array}$ & $\begin{array}{l}\text { be hungry (complementary } \\
\text { clause) }\end{array}$ & $\begin{array}{l}\text { Onaka ga suita ni natta replaces onaka ga } \\
\text { suichatta }\end{array}$ \\
\hline 4 & $\begin{array}{l}\text { Taman Safari e iku to } \\
\text { mado no kuruma kara } \\
\text { doubutsu ga miraresou } \\
\text { desu. }\end{array}$ & $\begin{array}{l}\text { Taman Safari e iku to } \\
\text { kuruma no mado kara } \\
\begin{array}{l}\text { doubutsu ga miraresou } \\
\text { desu. }\end{array}\end{array}$ & $\begin{array}{l}\text { DM (car window) to MD } \\
\text { (car window) (Noun } \\
\text { phrase) }\end{array}$ & $\begin{array}{l}\text { Mado no kuruma replaces kuruma no } \\
\text { mado }\end{array}$ \\
\hline 5 & $\begin{array}{l}\text { Shokudo ni tsuita yo. } \\
\text { Suwatte wa doko? Chotto } \\
\text { tatte moraeru. Mienai yo. }\end{array}$ & $\begin{array}{l}\text { Shokudo ni tsuita yo. } \\
\text { Suwatte iru basho wa } \\
\text { doko? Chotto tatte } \\
\text { moraeru. Mienai yo. }\end{array}$ & $\begin{array}{l}\text { Where shoud we sit? } \\
\text { (prepositional clause) }\end{array}$ & $\begin{array}{l}\text { Suwatte wa doko? missing some part of the } \\
\text { clause (loss of feature) : suwatte iru basho } \\
\text { wa doko? }\end{array}$ \\
\hline 6 & $\begin{array}{l}\text { Kinou no jugyou wa konai } \\
\text { ka na. no-to o kashite } \\
\text { moraenai ka na. }\end{array}$ & $\begin{array}{l}\text { Kinou no jugyou ni dete } \\
\text { inai node. no-to o } \\
\text { kashite moraenai ka na. }\end{array}$ & $\begin{array}{l}\text { Not attending class (verb } \\
\text { clause) }\end{array}$ & $\begin{array}{l}\text { Jugyou wa konai ka na replaces jugyou ni } \\
\text { dete inai node) }\end{array}$ \\
\hline 7 & $\begin{array}{l}\text { Mou sugu tanjoubi no } \\
\text { tomodachi da. }\end{array}$ & $\begin{array}{l}\text { Mou sugu tomodachi no } \\
\text { tanjoubi da. }\end{array}$ & $\begin{array}{l}\text { Form DM (tanjoubi no } \\
\text { tomodachi) to MD } \\
\text { (tomodachi no tanjoubi) } \\
\text { (Nominal phrase) }\end{array}$ & $\begin{array}{l}\text { Tanjoubi no tomodachi replaces tomodachi } \\
\text { no tanjuoubi }\end{array}$ \\
\hline 8 & $\begin{array}{l}\text { ii yo. Boushi wa } \\
\text { kashiageru. }\end{array}$ & $\begin{array}{l}\text { ii yo. Boushi wa } \\
\text { kashiteageru. }\end{array}$ & (I) borrow (verb clause) & Kashiageru replaces the verb kashiteageru \\
\hline 9 & $\begin{array}{l}\text { Rizuka-san wa keekio } \\
\text { tsukutta jouzu } \\
\text { desu. }\end{array}$ & $\begin{array}{l}\text { Rizuka-san wa jouzuni } \\
\text { keeki o tsukurimashita. }\end{array}$ & $\begin{array}{l}\text { Rizka is good at making } \\
\text { cakes (sentence structure) }\end{array}$ & $\begin{array}{l}\text { Sentence structure: S-particle assignment } \\
\text { (wa)-O-particle case(o)-P-Adjective } \\
\text { replacing the sentence structure: } \mathrm{S} \text {-particle } \\
\text { assignment(wa)-adjective(ni)-O-P } \\
\text { (replacement) }\end{array}$ \\
\hline 10 & $\begin{array}{l}\text { Watashi wa tomodachi to } \\
\text { tanbo de asobashi, kawa } \\
\text { de oyogu shi, chiisai } \\
\text { sakana o tsuru shi, guaba } \\
\text { no ki o nobotte imashita. }\end{array}$ & $\begin{array}{l}\text { Watashi wa tomodachi } \\
\text { to tanbo de asondari, } \\
\text { kawa de oyoidari, chiisai } \\
\text { sakana o tsuttari, guaba } \\
\text { no ki o nobottari } \\
\text { shimashita. }\end{array}$ & $\begin{array}{l}\text { My friends and I played in } \\
\text { the fields, swam in the } \\
\text { river, fished for small fish, } \\
\text { and climbed the guava tree. } \\
\text { (sentence structure) }\end{array}$ & $\begin{array}{l}\text { The equivalent compound sentence } \\
\text { structure which states several actions is } \\
\text { expressed by the sentence structure: } \sim \text { shi, } \\
\sim \text { shi, } \sim \text { masu. It Replaces the sentence } \\
\text { structure: } \sim \text { tari, } \sim \text { tari, } \sim \text { masu. } \\
\text { (replacement) }\end{array}$ \\
\hline 11 & $\begin{array}{l}\text { Malang ni Bijutsukan no } \\
\text { Angkut ga dekimashita. }\end{array}$ & $\begin{array}{l}\text { Malang ni Angkut no } \\
\text { Bijutsukan ga } \\
\text { dekimashita. }\end{array}$ & $\begin{array}{l}\text { In Malang, there is already } \\
\text { an Angkut Museum. } \\
\text { (Transport Museum: Noun } \\
\text { Phrases) }\end{array}$ & $\begin{array}{l}\text { Form DM (Bijutsukan no Angkut) } \\
\text { becomes MD (Angkut no Bijutsukan) } \\
\text { (replacement) }\end{array}$ \\
\hline 12 & $\begin{array}{l}\text { Jibun no anime ga hontou } \\
\text { ni miraretai_desu. }\end{array}$ & $\begin{array}{l}\text { Jibun no tsukutta anime } \\
\begin{array}{l}\text { ga hontou ni miraretai } \\
\text { desu. }\end{array}\end{array}$ & $\begin{array}{l}\text { Self-made anime } \\
\text { (supplementary clause) }\end{array}$ & $\begin{array}{l}\text { Jibun no anime replaces jibun no tsukutta } \\
\text { anime. }\end{array}$ \\
\hline 13 & $\begin{array}{l}\text { Iku no mae ni, ressha } \\
\text { chiketto o katte okimasu. }\end{array}$ & $\begin{array}{l}\text { Iku mae ni, ressha } \\
\text { chiketto o katte okimasu. }\end{array}$ & $\begin{array}{l}\text { Before leaving (time } \\
\text { marker prepositional } \\
\text { phrase) }\end{array}$ & Iku no me ni replaces iku mae ni \\
\hline 14 & $\begin{array}{l}\text { Watashi wa gakusei no } \\
\text { nihon bungaku desu. }\end{array}$ & $\begin{array}{l}\text { Watashi wa nihon } \\
\text { bungaku no gakusei } \\
\text { desu. }\end{array}$ & $\begin{array}{l}\text { Japanese Literature } \\
\text { Student (Noun Phrases) }\end{array}$ & $\begin{array}{l}\text { The form of DM in Indonesian influences } \\
\text { the speaker to say: Gakusei no nihon my } \\
\text { flower which replaces MD (nihon bungaku } \\
\text { no gakusei) }\end{array}$ \\
\hline 15 & $\begin{array}{l}\text { Tomodachi wa kinou saifu } \\
\text { o wasurete shimaimashita. }\end{array}$ & $\begin{array}{l}\text { Tomodachi wa kinou } \\
\text { saifu o motte iku no o } \\
\text { wasurete shimaimashita. }\end{array}$ & $\begin{array}{l}\text { Forgot to bring a wallet } \\
\text { (verb clause) }\end{array}$ & $\begin{array}{l}\text { Saifu o wasurete shimaimashita (forgot } \\
\text { wallet) replaces and removes some features } \\
\text { (replacement and loss features) from the } \\
\text { clause: saifu o motte iku no o wasurete } \\
\text { shimaimashita (forgot to bring wallet) }\end{array}$ \\
\hline
\end{tabular}

Based on Table 2, there were 15 cases of interference where psychological constraints occurred during data collection. To ascertain the cause of the psychological constraints in using Japanese, the researcher then conducted interviews with all respondents. A summary of the interviews is presented in Figure 2. 


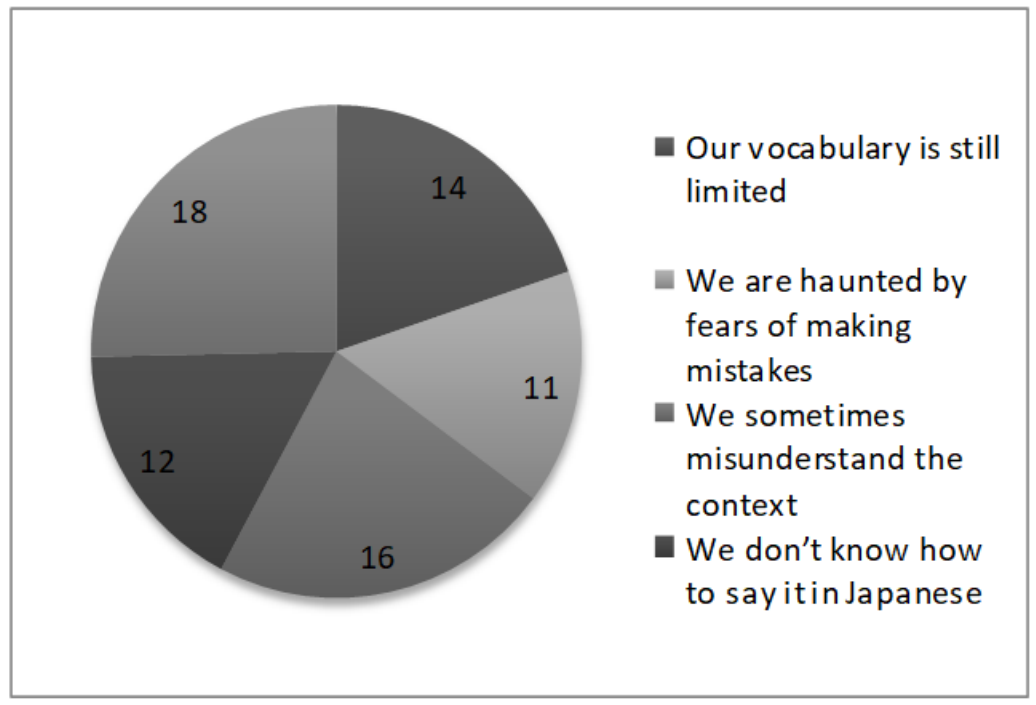

Figure 2. Summary of The Interview Responses

The number and percentage of interview respondents experiencing various types of psychological constraint on speaking Japanese is shown in Table 3. The results of these interviews are important for Japanese language teachers to help them know how to find effective Japanese language teaching strategies to obtain maximum results.

TABLE 3

THE CAUSES OF PSYCHOLOGICAL CONSTRAINTS ON SPEAKING JAPANESE

\begin{tabular}{|c|l|c|}
\hline No & \multicolumn{1}{|c|}{ PSYCHOLOGICAL CONSTRAINTS } & PERCENTAGE (N20) \\
\hline 1 & Our vocabulary is still limited & $14(70 \%)$ \\
\hline 2 & We are haunted by fears of making mistakes & $11(55 \%)$ \\
\hline 3 & We sometimes misunderstand the context & $16(80 \%)$ \\
\hline 4 & We don't know how to say it in Japanese & $12(60 \%)$ \\
\hline 5 & Feeling less confident & $18(90 \%)$ \\
\hline
\end{tabular}

\section{B. Discussion}

Japanese has different characteristics from Indonesian. This can be seen from the differences in the field of syntax. In the Indonesian phrase structure, the element D (explained/core) precedes the element M (explains/not the core); however, on the contrary, in Japanese noun phrases the element M precedes the element D. In the cases taken from interviews in Table 2 above, students were affected by Indonesian when speaking Japanese: for example, the Japanese literature students mentioned Museum Angkut, with the Japanese phrase pronounced as Bijutsukan no Angkut (it should be: Angkut no Bijutsukan). Other examples include tomodachi no watashi (it should be watashi no tomodachi) and Gakusei no Nihon Bungaku (it should be: Nihon Bungaku no Gakusei).

In the verb clause data, interference cases are often encountered because in Indonesian, there is no conjugation or verb change to express various different conditions such as the relative timeframe. Complementary clauses arise because of differences in the use of expressions in the conversational language used when communicating. This is because Japanese has a high dependence on certain contexts and has its own rules regarding the expressions used when communicating.

In the phenomenon of language contact that occurs in student speech, the occurrence of interference is influenced by language; in particular, interference is influenced by bilingualism. Interference at the clause level is caused by the fact that clauses in Japanese, especially verb clauses, need to be altered or conjugated (doushi no katsuyou) according to the form of the sentence. Doushi no katsuyou is a change of verb from the basic verb to a positive form, negative form, past form, conjunctive form, invitation form, command form and other forms.

To get used to using verb changes in Japanese, students must memorize and become used to making sentences with verb changes according to the context. Verbs in Japanese undergo changes or conjugations according to their group. These changes cause students to experience psychological constraints when using verbs. Another obstacle is that students are more responsive in the written language than in the spoken language.

Findings in this study included the formation of the verb, where --yatte iru replaced the verb yaru; the verb form tte iru means the verb indicates the activity being carried out, while the verb yaru expresses the future tense. Verb clauses are used in other complements such as kashiageru being used to replace the verb kashiteageru. The context in sentences with kashiageru verbs is different from that of kashiteageru verbs. Verbs that are given the affixes --ageru and --kureru indicate an act of giving or receiving that is done with kindness. The use of Japanese verbs based on their changes and context in sentences still experiences interference from the Indonesian language when students use them to 
communicate. This is also seen in Rizka is good at making cakes, pronounced as: keeki o tsukutta jouzu desu. In a proper sentence structure, the position of the adjective is in front of the predicate, namely the verb to make: jouzuni keeki o tsukurimasu.

The influence of language contact on the speech of Indonesian Japanese language learners undergoes an adaptation process in code-switching, code alternation, passive familiarity, negotiation, second language acquisition strategies, first language acquisition effects, and deliberate decision. In addition, the influence of the structure of the Japanese language which is syntactically different from Indonesian is also a major obstacle.

\section{CONCLUSION}

This study shows the influence of the speaker's mother tongue, namely Indonesian, on the spoken Japanese language. The speakers were native Indonesian speakers with different abilities who were learning Japanese. These students have generally met and talked to Japanese people, but in the phenomenon of language contact that occurs between Indonesian and Japanese, these students still experience the influence of their mother tongue, especially at the syntactic level.

When encountering a different language system and structure, the performance of students experienced interference due to the strong influence of the mother tongue, namely Indonesian. Although the interviews were delivered in Japanese, the students made several speeches with language structures adapted to their mother tongue, namely Indonesian, despite the many differences in systems or the linguistic level of the two languages.

In the process of learning a second language or becoming bilingual through the process of acquiring a second language, it was found that there was an inter-lingual transfer error or an error in the transfer process between languages which was influenced by the structure of the mother tongue when communicating using a foreign language; in this case, the structure of the Indonesian language affected Japanese language usage. In this study, when the students spoke during interviews, the Japanese spoken structure used was affected by the structure of the Indonesian language.

In communicating through verbal expressions, the students used speech with sentence patterns that are adapted to oral speech patterns, in that they placed adjectives or adverbs in their speech without paying attention to standard Indonesian sentence patterns. In terms of sociolinguistics, further study is needed to elucidate other factors which cause changes in the way the target language is spoken, resulting in interference or other forms of influence.

\section{REFERENCES}

[1] Aziz, et al. (2019). Second Language Interference towards First Language Use of Japanese Learners. IJELTAL (Indonesian Journal of English Language Teaching and Applied Linguistics) 4(1). 159-176

[2] Darwis, M., \& Kamsinah. (2019). Sumbangan Bahasa Indonesia Terhadap Pemekaran Kosakata Bahasa Bugis: Kasus Penggunaan Bahasa Bugis Pada Media Sosial Facebook (The Contribution Of Indonesian Language On Buginese Vocabulary Development: A Case Study Of The Use Of Buginese On Facebook Social Media). Sawerigading 25(2).

[3] Dixon, \& Sally. (2020). Bilingualism in the Community: Code-Switching and Grammars in Contact. Australian Journal of Linguistics 40(2).

[4] Donnelly, et al. (2019). Is There a Bilingual Advantage on Interference-Control Tasks? A Multiverse Meta-Analysis of Global Reaction Time and Interference Cost. Psychonomic Bulletin and Review 26(4).

[5] Galkina, A., \& Alexandra, V. R. (2019). Grammatical Interference in Written Papers Translated by Russian and American Students. Training, Language and Culture 3(3).

[6] Holmes, J. (2013). An Introduction to Sociolinguistics. New York: Routledge.

[7] Iman, \& Topan, R. (2020). The Interference of Indonesian on English Second Language Writing. Journal of Languages and Language Teaching 8(2): 170-182.

[8] Junaidi, J., et al. (2020). Artificial Intelligence in EFL Context: Rising Students' Speaking Performance with Lyra Virtual Assistance. International Journal of Advanced Science and Technology Rehabilitation, 29(5), 6735-6741.

[9] Kafryawan, W., Abdul, H. Y., \& Nasmilah. (2018). The Influence of Intelligence on Student's Speaking Skills. ELS Journal on Interdisciplinary Studies in Humanities 1(2).

[10] Khresheh, \& Asim, M. (2020). A Psycholinguistic Review of the Interface of Implicit and Explicit Knowledge: The Case of Bilingual Speakers Using L2 as a Foreign Language. International Journal of English Language and Literature Studies 9(4).

[11] Krashen, et al. (1998). The Natural Approach (Language Acquisition in the Classroom). Prantice Hall Europe.

[12] Krashen, S. (1989). Language Acquisition and Language Education - Extensions and Applications.

[13] Miranda, \& Ivan, R. M. (2012). Insights on Bilingualism and Bilingual Education: A Sociolinguistic Perspective. Íkala 17(3):263-72.

[14] Novianti, Nalti, \& Is, A. D. (2008). Analisis Interferensi Dalam Kelas Kata Keishiki Meishi Khususnya Penggunaan Tame Ni Dan You Ni. Lingua Cultura 2(1).

[15] Paola, C. S. (2020). The Use of Digital Portfolios to Enhance English as a Foreign Language Speaking Skills in Higher Education. International Journal of Emerging Technologies in Learning Vol. 15, N.

[16] Perta, \& Carmela. (2020). Sociolinguistic Aspects and Language Contact: Evidence from Francoprovençal of Apulia. Journal of Language Contact 13(2).

[17] Purba, \& Norita. (2018). The Role of Psycholinguistics in Language Learning and Teaching. Tell: Teaching of English Language and Literature Journal 6(1).

[18] Rahmayana, M. R., Hasmawati, \& Muddin. (2018). Interferensi Pola Kalimat Bahasa Indonesia Terhadap Keterampilan Berbicara Bahasa Jerman Siswa. Eralingua: Jurnal Pendidikan Bahasa Asing Dan Sastra 2(2). 
[19] Rahman, et al. (2019). Facebook Group as Media of Learning Writing in ESP Context: A Case Study at Hasanuddin University. Asian EFL Journal Research Articles, 26(6.1), 153-167.

[20] Sarfraz, S., Zahida M., \& Raheela, T.(2016). Analysis of Grammatical Interference and Its Social Acceptability in Pakistani Context. Procedia - Social and Behavioral Sciences 232.

[21] Sarif, S., Irzam, \& Dadang, S. (2020). Interferences Of English-Japanese Language In The Covid-19 Pandemic. IZUMI 9(2).

[22] Shin, G. H. \& Boo, K. J. (2021). Input-output relation in second language acquisition: Textbook and learn writing for adult English-speaking beginners of Korean. Australian Review of Applied Linguistics. p. 1-25. DOI: https://doi.org/10.1075/aral.20049.shi

[23] Sugianto, \& Kamarudin. (2021). The Interferences Of Sasak Language On English Vocabulary Mastery. Journal of Languages and Language Teaching 9(1).

[24] Thomason, S. G. (2001). Language Contact; An Introduction. Edinburgh University Press.

[25] Tjandra, \& Sheddy, N. (2013). Sintaksis Jepang. Jakarta: Binus Media Publishing.

[26] Tjandra, \& Sheddy, N. (2015). Morfologi Jepang. Jakarta: Binus Media Publishing.

[27] Vavilova. (2015). Genre Interference in the Process of Foreign Language Speaking Training. Procedia - Social and Behavioral Sciences 215 .

[28] Weda, S., et al. (2021). Factors Affecting Students' Willingness to Communicate in EFL Classroom at Higher Institution in Indonesia. International Journal of Instruction, 14(2), 719-734.

[29] Wardaugh, R., \& Ronald. (2006). An Introduction to Sociolinguistics. 5th ed. Oxford. Victoria, Australia, Blackwell Publishing.

[30] Weinreich, U. (2010). Languages in contact. De Gruyter Mouton. University of Pennsylvania, Department of Linguistics.

[31] Wuisang, J. R. R. (2019). Contextual Approaches In Kaiwa Learning (Speaking) Japanese Language. Journal Of Educational Method And Technology 2, no.1.

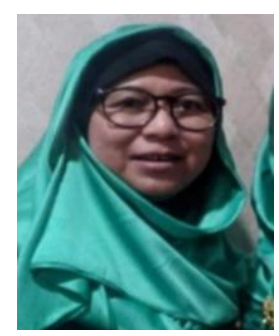

Suyanti Natalia is a postgraduate student at Hasanuddin University. She has worked as a senior lecturer at the Nasional University, Indonesia

Muhammad Darwis is a senior professor at Hasanuddin University, Indonesia.

Kaharuddin is a lecturer at Hasanuddin University, Indonesia.

Asriani Abbas is a lecturer and the chairwoman of the Indonesian Language Master's Study Program (S2 Bahasa Indonesia) at Hasanuddin University, Indonesia. 